\title{
Learning Self-regulated L2 WritingUnder a Cognitive Model
}

\section{Mrs Manashi Gogoi Dutta}

King Mongkut's Institute of Technology Ladkrabang

Thailand

\section{Dr UthaivanDanvivath}

Confucius Institute of Khonkaen University

Thailand

Article History: Received:11 January 2021; Accepted: 27 February 2021; Published online: 5 April 2021

\begin{abstract}
This innovative approach of teaching L2 writing was experimentedbelieving that using a fewer selfregulated learning strategymay lead toweakmetacognitive learning attitude resulting in low proficiency. This research wasconducted to investigate the consequences of instructionally aroused cognitive involvement load for using self-regulated and metacognitive learning strategies to improve L2 writing skills. The innovative L2 writing instructional model of this study has been named as Strategic Self-Regulated Metacognitive Activities or $\mathrm{S}^{2} \mathrm{RMCA}$.The approach of this model is to promoteself-regulated learning managementby learners. Forarousing the use of learning strategies, a set of self-monitoring and self-evaluatingassessment rubric namedStrategy Inventories for Learning L2 Writing(SILL2W)has also been designed. For collecting and analyzingthe data a questionnaire, pre-post-tests, checklist, and interviews wereutilized. Outcomes of data analyses have shownusefulness and practicality ofthe S RMCA model for teaching self-regulated L2 writing. Acceptable resultshave also beenshownby participants intheir L2 writing skills. In research studies conducted on cognitive load, accurate measurement of load viaself-reporting has been a persistingquestion and this study has notbeen different from the onesthat have faced the challenge.
\end{abstract}

Keywords:L2 writing, self-regulated learning, metacognitive learning strategies and cognitive involvement load

\section{Introduction}

Several researchstudies have shownsolid correlation among self-regulation, language learning strategies, metacognition and cognitive involvement load from different angles and viewpoints.Cubukcu (2009) has portrayed therelationship between self-regulation, metacognition, and autonomy and demonstrated that low autonomy is closely related to low self-regulatedbehaviors in learning. Chamot and Harris (2019) have asserted thatpromisingevidenceis still anticipatedrelating to how to design and implement the language learning strategy mediations. Evans, Kirby, and Fabrigar (2003) have claimedthat there is synchronous interplay amongthe processes of writing, learning approaches and self-regulation. Farrington and colleagues (2012) have directedat researcher specified learning strategies asthe limitationsof existingstudies that are not essentiallyselected by teachers or learners.Raya (2011) has discussed about the important role played by teachersin creating learning opportunities that can supportself-regulationand reflectivity of learners. In the domain of language learning strategies and self-regulated learning,research has rarely been meant to have an influence on classroom practices (Conley, 2014). As asserted by Conley, it is even hard to design such research. There are not enough models to train teachers on instructional models that can foster self-regulated learning of L2 writing. This study has come forward with an innovative model of teaching and learning L2 writing — Strategic Self-Regulated Metacognitive Activities ( $\mathrm{S}^{2} \mathrm{RMCA}$ ) for fostering self-regulated and metacognitive learning strategies through instructionally stimulated cognitive involvement load on learning processes. $\mathrm{S}^{2} \mathrm{RMCA}$ is designed to engage learners in self-controllingtheirparticipation in planning, self-monitoring, and self-evaluation.

\section{Literature Review and Conceptual Framework}

Literature engaging learners to achieve their goalsthrough self -regulated learning, explaining,modelling, and scaffoldingof the learning strategies to students in regular classrooms are needed (Pressley, Lindsay, Fingeret, Reffitt, \& Raphael-Bogaert 2007).Issues like relationship of theoretical underpinnings with strategy trainingand successful learningneed attention (Gkonou\&Inceçay, 2016). Focus of some recent studieshave been the relationships among thelanguage learning strategies and self-regulation (Rose, 2012; Chamot, 2018; Griffiths, 2013; Oxford, 2018).Requirements of active engagement and involvement of the learners in the process of learning were discussed (Cotterall, 2000; Zimmerman \& Schunk, 2008). Very little is exploredabout associatinglearners' thinking with the production in texts. Sub processesincluded in the Hayes and Flower's (1980) model were translating thoughts into texts andexamining in relation to a learner's long-term memory and a task environment. Hayes (2012) has restructuredhispreviousmodeland formed a control over level of motivation, setting goals, planning, and writing schemata. Studies have also examined sub processes of L2 writing in terms of revising, fluency of text generating, and restructuring of texts (Hall, 1990; Chenoweth \& 
Hayes, 2001; Larios, Murphy \&Manchón, 1999). Some other studies have compared cognitive strategy use between L1 and L2 writing (Arndt, 1987; Whalen \& Menard, 1995; Cummimg, 1989; Sasaki, 2000). This studyhas looked at self-regulated learning as learners having control over their own thinking, using metamemory, choosing learning strategies and learning behavior to solve problems in developing L2 writing.Pour-Mohammadi, Zainol and Cheong Lai, (2012) have claimed thatuseful and strategic mediations of language learning strategiescan support to improve L2 writing. In the S RMCA model, concentrating, processing information, extracting meaning, organizing ideas,composingtexts,ordeveloping sentences and paragraphs, monitoring own compositions, engaging with study aids, and understanding the tasksare listed as metacognitive strategies. Tseng, DÖrnyei, and Schmitt (2006) have not included the learning strategies in their effort to evaluate "strategic-learning". R. Oxford and Amerstorfer (2018) have claimed that there has been still a voidparticularlyin the instructional modelling of teaching self-regulated L2 writing. Lack of resources as well as guidance forquantifying use of learning strategiesby learners in classroom environmentsis a significantchallenge at present(Gunning, 2011). For facilitating self-regulated and metacognitive learning strategy use, this study has developed a self-questioning checklist - Strategy Inventories for Learning L2 Writing (SILL2W)with 40 inventory items.SILL2W has been designed especially in self-questioning formto help facilitate self-monitoring and self-evaluation of L2 writing.Oxford (2017) has claimed that there are less information sources of cultivating self-regulated and metacognitive learning strategies for L2 writing skills. The S RMCA model is inspired byS-W-SR (Weinstein and Palmer, 2002) and ER-GO-CA (Olejnik and Nist, 1992).The study of Phoocharoensil, S., Moore, B., Gampper, C., Geerson, E., Chaturongakul, P., Sutharoj, S., and Carlon, W. (2016) has revealed someproblems that Thai EFL undergraduate students often encounter in L2 writing are due to not only L1 influence, but also due to confusion over the target language and its complexgrammatical system. As cited in Nopmanotham (2016, p. 37), the study conducted by Pimsan (2003) has revealed that mainly metacognitive, cognitive, social, and affective strategies in L2 writing have been the lower strategies used by Thai graduate students. Table 1 below shows the components and the self-regulated and metacognitive learning strategies of the $\mathrm{S}^{2} \mathrm{RMCA}$ model.

Table $1 S^{2}$ RMCA model of this study

\begin{tabular}{|c|c|c|c|c|c|}
\hline Model & Components & Self-regulation st & rategies & & \\
\hline S-W-SR & Self-regulation & Concentration & Self-testing & Study aids & $\begin{array}{l}\text { Time } \\
\text { management }\end{array}$ \\
\hline ER-GO-CA & \begin{tabular}{|l|} 
Cognitive \\
activities
\end{tabular} & $\begin{array}{l}\text { Selecting main } \\
\text { ideas }\end{array}$ & Self-testing & Study aids & $\begin{array}{l}\text { Information } \\
\text { processing }\end{array}$ \\
\hline $\begin{array}{l}\mathrm{S}^{2} \mathrm{RMCA} \\
\text { (Instructional } \\
\text { model) }\end{array}$ & $\begin{array}{l}\text { Self-regulated } \\
\text { metacognitive } \\
\text { learning } \\
\text { activities }\end{array}$ & $\begin{array}{l}\text { Learning } \\
\text { management - } \\
\text { Concentration, } \\
\text { time } \\
\text { management, } \\
\text { extracting } \\
\text { meaning, seeking } \\
\text { and organising } \\
\text { ideas, developing } \\
\text { sentences and } \\
\text { paragraph } \\
\text { patterns, } \\
\text { monitoring own } \\
\text { composition, } \\
\text { engagement with } \\
\text { learning } \\
\text { materials, } \\
\text { understanding } \\
\text { task } \\
\text { requirements. }\end{array}$ & $\begin{array}{l}\text { Self-monitoring } \\
\text { and self- } \\
\text { evaluation }\end{array}$ & Study aids & \\
\hline
\end{tabular}

DÖrnyei and Ryan (2015) haveargued that research have not achievedanyanswerto the primaryconcernsabout what splits strategic learning activities from regular learning activities. Macaro (2006) has 
stated that learning strategies are located in the working memory and Oxford (2017) has argued that application of learning strategies require working memory. On the other hand, Sweller (1988) has hinted that working memory has limitedability to keep information.Recommendations of Cognitive Load Theory have beenbeneficial for designing teaching and learning materials to handle learners' working memory for successful learning.Involvement Load Hypothesis (ILH) of Laufer and Hulstijn (2001) has stated that when there is higher involvement load on the learning processes, there is more effective learning. This study hasdevelopedinstructional materials to stimulatecognitive involvement load on learners to manage self-regulated learning of L2 writing. Conley (2014) has advised that students should be trained to monitor the use of learning strategies through self-evaluation and peer feedback. Oxford and Amerstorfer (2018) have claimed that the relationships of multiple factors of self-regulated language learning strategies, contexts, and individual differences can be brought together in strategy instructions to meet up the requirements of learners with distinct proficiencies. Studieshave tried to meet individual learners' goals and characteristics (Oxford, 2018; Chamot\& Harris, 2019). Cao, Y. (2012) has reported that training of metacognitive strategy could show positive results in web-based English learning.Grounded on the thoughtsas describedabove, this study has made an effort to responseto the following research questions.

1 Can the $S^{2}$ RMCA model help L2 writing learners tobe self-regulated in a regular classroom environment and improve L2 writing skills?

2 Whether instructionally induced cognitive involvement load can promote learners' self-regulated and metacognitive learning strategies?

\section{Method}

This study was carried out as an experimentto promoteuse of self-regulated and metacognitive learning strategies by 26 Thai undergraduate engineering studentsdivided into three groups. Duration of the research was an academic semester of 17 weeks.Groups A and B were taught under the instructional model of this study. Group $\mathrm{C}$ students did not receive the treatment oftask demandsforstimulating cognitive involvement load. Because of thenature of participation, Group $\mathrm{C}$ can be marked as the control group. In the starting of the semester, students were informedabout self-regulated learning approach and use of self-regulated and metacognitive language learning strategies. A survey was conductedto assess theself-regulated and metacognitive learning strategy use by thestudents.Research tools of this study were of two types - Instructional and Testing. Data analysesweredone to gather information regarding the influence of instructionally induced cognitive load on the learners thinking processes and to notice the impacts of using self-regulated and metacognitive learning strategies in L2 writing.Tools of data collectionwereself-reports, a semi-structured questionnaire, observation, a survey questionnaire, pre-post test scores, and two online tools.

\section{Data analyses and Findings}

The analyses started withexamining the reliability and validity of the instructional instrument SILL2W through multiple statistical tests for each group of participants and for each category of learning strategiesindependently. Total 40 learning strategies have been included in the SILL2W construct coveringthe areas of motivation, self-correction, self-regulation, and metacognition. Table2below shows the results for the self-regulation strategies and table 3 shows the results for the metacognitive strategies. The reliability coefficient for Group A is [0.633] for self-regulation items [1, 3, 4] and for items [5, 6, 7], the reliability coefficient is [0.606]which are relatively lower than [.70]. The results of the Cronbach's Alpha for selfregulation strategy use of Group B students demonstrate that for items $[4,5,6]$, the reliability coefficient is [0.863] which is higher than [.70] indicating that the items $[4,5,6]$ have relatively high internal consistency and are therefore "acceptable". For items $[1,3,7]$, the reliability coefficient is [0.702] which is higher than [.70] and therefore "acceptable" for Group B. The results of the Cronbach's Alphameasure for the self-regulation strategy use of Group C students show that for items [1, 2, 7] the reliability coefficient is [0.789] which is higher than [.70] indicates that the items $[1,2,7]$ have relatively high internal consistency and are therefore "acceptable". The Cronbach's Alpha finding for items [4, 5, 6], shows the reliability coefficient as [0.700] which is statistically "acceptable" for Group C.It is noteworthy that SILL2W is domain and context specific because its variables include common errors of Thai L2 learners in English writing. 
Table 2Cronbach's Alpha measure of internal consistency and reliability statistics for the self-regulation strategies of SILL2W

$\begin{array}{ll}\text { Group A } & \text { Cronbach's Alpha } \\ \text { Self-regulation_1,3,4 } & 0.633 \\ \text { Self-regulation_5,6,7 } & 0.606 \\ \text { Group B } & \text { Cronbach's Alpha } \\ \text { Self-regulation_4,5,6 } & 0.863 \\ \text { Self-regulation_1,3,7 } & 0.702 \\ \text { Group C } & \text { Cronbach's Alpha } \\ \text { Self-regulation_1,2,7 } & 0.789 \\ \text { Self-regulation_4,5,6 } & 0.700\end{array}$

Table 3 below exhibits the outcomes of the Cronbach's Alpha measure of internal consistency and reliability statistics of the metacognitive strategies of SILL2W.

Table 3Cronbach's Alpha measure of internal consistency and reliability statistics for the metacognitive statistics of SILL2W

$\begin{array}{ll}\text { For Group A, B \& C } & \text { Cronbach's Alpha } \\ \text { Metacognitive_2,5,6,9,10,13 } & 0.929 \\ \text { Metacognitive_3,4,8,15,17 } & 0.883 \\ \text { Metacognitive_11,14,16 } & 0.756\end{array}$

The reliability coefficient for the metacognitive items $[2,5,6,9,10,13]$ is $[0.929]$, for items $[3,4,8,15$, 17] the reliability coefficient is [0.883] and for the items $[11,14,16]$ the reliability coefficient is $[0.756]$ which indicates that the metacognitive items $[2,3,4,5,6,8,9,10,11,13,14,15,16,17]$ are statistically significant and acceptable. The online assessment toolsassessedwritingperformancesin terms ofCEFR level, IELTS level, number of words, average sentence length, average word length, word complexity, and the Flesch-Kincaid Grade Level. The mean ranks of CEFR and IELTS levels went up from [11.38] of pre testto [20.083] and [15.333] in post test. As seen in table 4, the mean ranks for all the areas of online assessments for Group A have shown improvements. For Flesch-Kincaid Grade levels, the mean ranks went up from [10.88] to [18.000] in week 16. For number of words, the mean rank [13.69] of the first task in week 2 went up to [17.208] in the final drafts and to [26.333] in the post test scores. For average sentence lengths, mean rank scores went from [10.81] of pre test to [19.250] for drafts 3 and [18.417] in post test. Mean rank for average word length was [10.85] in week 2. Whereas the mean rank for the final drafts was [20.333] and the mean rank for the report writing task's average word length was [18.833]. The mean rank for 'word complexity' scores was [12.38] in week 2 which went up to [19.333] and [16.042] in week 16.Participants were not provided with any readily available or any explicit instructions on the writing tasks. Learning was happening through self-monitoring and self-evaluation. Therefore, it can be interpreted that the improvements in writing show the effect of self-monitoring and selfevaluation. From week 2/3 till week 16, the mean ranks of Group A students' performances in three different L2 writing drafts have shown mostly upward or improving direction as seen in table 4.

Table 4Online test scores comparison with performance indicator arrows for Group A 


\begin{tabular}{|c|c|c|c|c|}
\hline \multicolumn{2}{|c|}{$\begin{array}{l}\text { Group A SANTORINI } \\
\text { compared with Sophia drafts } \\
\text { and Post test scores }\end{array}$} & \multirow{2}{*}{$\begin{array}{l}\begin{array}{l}\text { Numbe } \\
\text { r of } \\
\text { student } \\
\text { s }\end{array} \\
12\end{array}$} & \multirow{2}{*}{$\begin{array}{l}\text { Mean Ranks of } \\
\text { Santorini } \\
20.083\end{array}$} & \multirow[t]{2}{*}{$\begin{array}{l}\text { Mean Ranks of } \\
\text { Sophia }\end{array}$} \\
\hline CEFR level & Draft 2 & & & \\
\hline & Draft 3 & 12 & 20.083 & 15.62 \\
\hline & $\begin{array}{l}\text { Week } 16 \text { - } \\
\text { POST TEST }\end{array}$ & 12 & 15.333 & \\
\hline \multirow[t]{3}{*}{ IELTS level } & Draft 2 & 12 & 20.083 & 11.38 \\
\hline & Draft 3 & 12 & 20.083 & 15.62 \\
\hline & $\begin{array}{l}\text { Week } 16- \\
\text { POST TEST }\end{array}$ & 12 & 15.333 & \\
\hline \multirow{3}{*}{$\begin{array}{l}\text { Flesch- } \\
\text { Kincaid } \\
\text { Grade level }\end{array}$} & Draft 2 & 12 & 19.042 & 10.88 \\
\hline & Draft 3 & 12 & 18.458 & 16.12 \\
\hline & $\begin{array}{l}\text { Week } 16- \\
\text { POST TEST }\end{array}$ & 12 & 18.000 & \\
\hline \multirow{3}{*}{$\begin{array}{l}\text { Number of } \\
\text { words }\end{array}$} & Draft 2 & 12 & 11.958 & 13.69 \\
\hline & Draft 3 & 12 & 17.208 & 13.31 \\
\hline & $\begin{array}{l}\text { Week } 16- \\
\text { POST TEST }\end{array}$ & 12 & 26.333 & \\
\hline \multirow{3}{*}{$\begin{array}{l}\text { Average } \\
\text { Sentence } \\
\text { length }\end{array}$} & Draft 2 & 12 & 17.833 & 10.81 \\
\hline & Draft 3 & 12 & 19.250 & 16.19 \\
\hline & $\begin{array}{l}\text { Week } 16- \\
\text { POST TEST }\end{array}$ & 12 & 18.417 & \\
\hline \multirow{3}{*}{$\begin{array}{l}\text { Average } \\
\text { Word length }\end{array}$} & Draft 2 & 12 & 15.833 & 10.85 \\
\hline & Draft 3 & 12 & 20.833 & 16.15 \\
\hline & $\begin{array}{l}\text { Week } 16- \\
\text { POST TEST }\end{array}$ & 12 & 18.833 & \\
\hline \multirow{3}{*}{$\begin{array}{l}\text { Word } \\
\text { complexity }\end{array}$} & Draft 2 & 12 & 19.625 & -12.38 \\
\hline & Draft 3 & 12 & 19.833 & 14.62 \\
\hline & $\begin{array}{l}\text { Week } 16- \\
\text { POST TEST }\end{array}$ & 12 & 16.042 & \\
\hline
\end{tabular}

In table 5 below, the Kruskal-Wallis test mean ranks for three writing tasks of Group B students (pre, mid and post) are presented. The scores in the Mean Rank column can be used to compare the differences in writing performances of week 2 and week 17. Students were involved in self-monitoring and self-evaluation to fend for and treat errors by using the SILL2W and the writing assessment rubrics. The differences in the mean scores can be interpreted as showing better performances because of increasing scores. The results of Group B show statistically significant differences in scores of pre, mid and post tests and number of words. However, Group B had 7 students and the sample size was relatively small for statistical analysis. Therefore, the scores of mean ranks (with arrow markers) can be considered for interpretation.

Table 5Kruskal-Wallis test mean ranks for Group B students (pre, mid and post) 


\begin{tabular}{|c|c|c|c|c|c|c|}
\hline \multicolumn{2}{|l|}{ Group B } & \multirow{2}{*}{\begin{tabular}{|l} 
N \\
7
\end{tabular}} & \multirow{2}{*}{\begin{tabular}{|l} 
Mean Rank \\
7.57 \\
\end{tabular}} & \multirow{2}{*}{\begin{tabular}{|l} 
Chi-Square \\
9.745
\end{tabular}} & \multirow{2}{*}{\begin{tabular}{|l|} 
df \\
2.000
\end{tabular}} & \multirow{2}{*}{\begin{tabular}{|l} 
Asymp. Sig. \\
0.008
\end{tabular}} \\
\hline Report Writing & Pre_test & & & & & \\
\hline & Mid test & 7 & 8.57 & & & \\
\hline & Post test & 7 & 16.86 & & & \\
\hline \multirow{3}{*}{$\begin{array}{l}\text { Number of } \\
\text { words }\end{array}$} & Pre_test & 7 & 7.71 & 11.273 & 2.000 & 0.004 \\
\hline & Mid test & 7 & $17.43 \downarrow$ & & & \\
\hline & Post test & 7 & 7.86 & & & \\
\hline \multirow[t]{3}{*}{ Sentence length } & Pre_test & 7 & 11.93 & 1.456 & 2.000 & 0.483 \\
\hline & Mid test & 7 & $8.71 \downarrow$ & & & \\
\hline & Post test & 7 & 12.36 & & & \\
\hline \multirow[t]{3}{*}{ Word length } & Pre_test & 7 & 10.29 & 2.312 & 2.000 & 0.315 \\
\hline & Mid test & 7 & 13.79 & & & \\
\hline & Post test & 7 & 8.93 & & & \\
\hline \multirow{3}{*}{$\begin{array}{l}\text { Word } \\
\text { complexity }\end{array}$} & Pre_test & 7 & 12.43 & 0.675 & 2.000 & 0.713 \\
\hline & Mid test & 7 & 9.71 & & & \\
\hline & Post test & 7 & 10.86 & & & \\
\hline \multirow[t]{3}{*}{ Flesch Kincaid } & Pre_test & 7 & 11.50 & 2.681 & 2.000 & 0.262 \\
\hline & Mid test & 7 & $8.07 \downarrow$ & & & \\
\hline & Post test & 7 & 13.43 & & & \\
\hline
\end{tabular}

A Wilcoxon Signed-Rank non-parametric statistical test was also run to evaluate the pre and post test scores in order to determine whether the group's population mean ranks varied through a paired difference test. Table 6 below shows the mean rank and sum of rank along with the negative and positive ranks in pre and post test scores of Group A, B and C.

Table 6Negative and positive ranks of pre and post test scores of Groups A, B and C

\begin{tabular}{|lllll|}
\hline Pre and post tests Mean Ranks of A, B, and C & $N$ & Mean Rank & Sum of Ranks \\
Group_A_Post-Group_A_Pre & Negative Ranks & $1^{\mathrm{a}}$ & 2.00 & 2.00 \\
& Positive Ranks & $12^{\mathrm{b}}$ & 7.42 & 89.00 \\
& Ties & $0^{\mathrm{c}}$ & & \\
& Total & 13 & & \\
Group_B_Post-Group_B_Pre & Negative Ranks & $0^{\mathrm{d}}$ & 0.00 & 0.00 \\
& Positive Ranks & $6^{\mathrm{e}}$ & 3.50 & 21.00 \\
& Ties & $1^{\mathrm{f}}$ & & \\
& Total & 7 & & \\
Group_C_Post-Group_C_Pre & Negative Ranks & $3^{\mathrm{g}}$ & 2.67 & 8.00 \\
& Positive Ranks & $3^{\mathrm{h}}$ & 4.33 & 13.00 \\
& Ties & $0^{\mathrm{i}}$ & & \\
& Total & 6 & & \\
& & & & \\
& & &
\end{tabular}


Table 7below shows the results of the Wilcoxon Signed-Rank test based on negative ranks.Group A's pvalue is [p=0.002] and Group B's p-value is [p=0.028]. Whereas for Group $C$, it is [p=0.600]. This presentsa convincing indication that the participantsof the experiment groups have shown improvement in the test scores. Experiment groups' performance scores attained through grading with the assessment rubrics showed significant differences whereasthe control group's performance did not show any significant difference between pre and post testscores.

Table 7Wilcoxon Signed-Rank test statistic based on negative ranks of Groups A, B and C

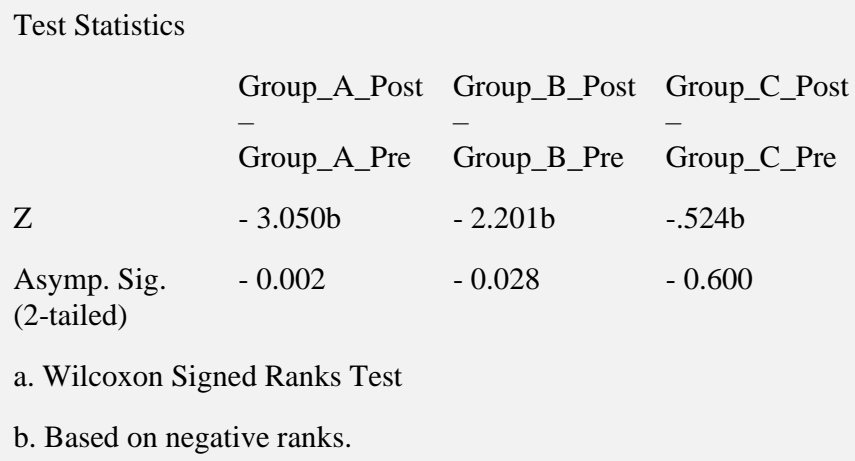

The self-reporting checklist has been designed to elicit students' opinions on experiences ofcognitive pressure for self-regulated learning. Table 8below shows the results of Chi-Square statistical difference in use of learning strategies based on the self-reports. A Chi-Square with low value meanshigh correlation between two sets of data.

Table 8Chi-Square statistic of strategy use by Group A, B, and C in the beginning of the semester

\begin{tabular}{|c|c|c|c|c|c|c|}
\hline \multicolumn{2}{|c|}{ Beginning of semester results } & \multicolumn{5}{|c|}{ Values } \\
\hline Strategies & Learners & $\mathrm{N}$ & Mean Rank & Chi-Square & df & Sig. \\
\hline \multirow[t]{3}{*}{ Motivation } & Group A & 13 & 13.69 & 8.720 & 2 & 0.013 \\
\hline & Group B & 7 & 25.71 & & & \\
\hline & Group C & 12 & 14.17 & & & \\
\hline \multirow[t]{3}{*}{ Self-correction } & Group A & 13 & 16.58 & 7.120 & 2 & 0.028 \\
\hline & Group B & 7 & 23.93 & & & \\
\hline & Group C & 12 & 12.08 & & & \\
\hline \multirow[t]{3}{*}{ Self-regulation } & Group A & 13 & 15.81 & 2.890 & 2 & 0.236 \\
\hline & Group B & 7 & 21.64 & & & \\
\hline & Group C & 12 & 14.25 & & & \\
\hline \multirow[t]{3}{*}{ Metacognitive strategies } & Group A & 13 & 15.69 & 2.284 & 2 & 0.319 \\
\hline & Group B & 7 & 21.14 & & & \\
\hline & Group C & 12 & 14.67 & & & \\
\hline
\end{tabular}

The Chi-Square statistic results for three groups display significantly different use of motivation and selfcorrection strategies whereas no significantly different use of Metacognitive and Self-regulation strategies in the beginning of the semester.In table 9, self-reports show only Group A's mean ranks of cognitive load at the beginning of the semester as [7.00] and at the end of the semester as [20.00]. The self-reporting ranks in table 
9indicate Group A students' experienceof having cognitive involvement loadas [0.000], use of learning strategies related to motivationas [0.001], for self-regulated strategiesas [0.005], for metacognitive strategies as [0.000],for use of technologyas [0.027] and doing self-correctionas [0.343]. Among the factors, according to Group A students' self-report, the highly significant ones are cognitive load, motivation strategies, selfregulatedand metacognitive strategies. Studentsreported significant differences in using technology as well except doing self-correction. Most of the self-reports mentioned not knowing how to correct the mistakes.

Table 9Results of the Mann-Whitney $U$ test comparing the strategy use of Group A

$\begin{array}{lllllll}\text { Strategies } & \text { Duration } & \begin{array}{l}\text { Students } \\ \text { number }\end{array} & \begin{array}{l}\text { Mean } \\ \text { Rank } \\ \text { Of } \\ \text { Strategy }\end{array} & \begin{array}{l}\text { Sum of } \\ \text { Ranks } \\ \text { R }\end{array} & \begin{array}{l}\text { Mann- } \\ \text { Whitney }\end{array} & \text { Sig. } \\ & & & 14.23 & 185.00 & \\ \text { Cog Load } & \text { Beginning } & 13 & 7.00 & 91.00 & 0.000 & 0.000 \\ & \text { End } & 13 & 20.00 & 260.00 & & \\ \text { Motivation } & \text { Beginning } & 13 & 17.73 & 230.50 & 29.500 & 0.001 \\ & \text { End } & 13 & 9.27 & 120.50 & & \\ \text { Self- } & \text { Beginning } & 13 & 17.35 & 225.50 & 34.500 & 0.005 \\ \text { regulation } & \text { End } & 13 & 9.65 & 125.50 & & \\ \text { Technology } & \text { Beginning } & 13 & 16.85 & 219.00 & 41.000 & 0.020 \\ & \text { End } & 13 & 10.15 & 132.00 & & \\ \text { Metacognitive } & \text { Beginning } & 13 & 18.58 & 241.50 & 18.500 & 0.000 \\ & \text { End } & 13 & 8.42 & 109.50 & & \\ & \text { Beginning } & 13 & 16.62 & 216.00 & 44.000 & 0.027 \\ \text { Self- } & \text { End } & 13 & 10.38 & 135.00 & & \\ \text { correction } & \text { Beginning } & 13 & 14.77 & 192.00 & 68.000 & 0.343 \\ & \text { End } & 13 & 12.23 & 159.00 & & \\ & & & & & & \end{array}$

Figure 1 displays Group A's self-report on cognitive load experience. 38.5\% students rated their experience at 4 out of [1 to 6]. $23.1 \%$ commented optionally [more than 6 or $6+$ ] that they were exhausted because of cognitive involvement load, but they could learn. 30.8\% students rated their experience at 3 and rest of the students rated their cognitive involvement load at 5.
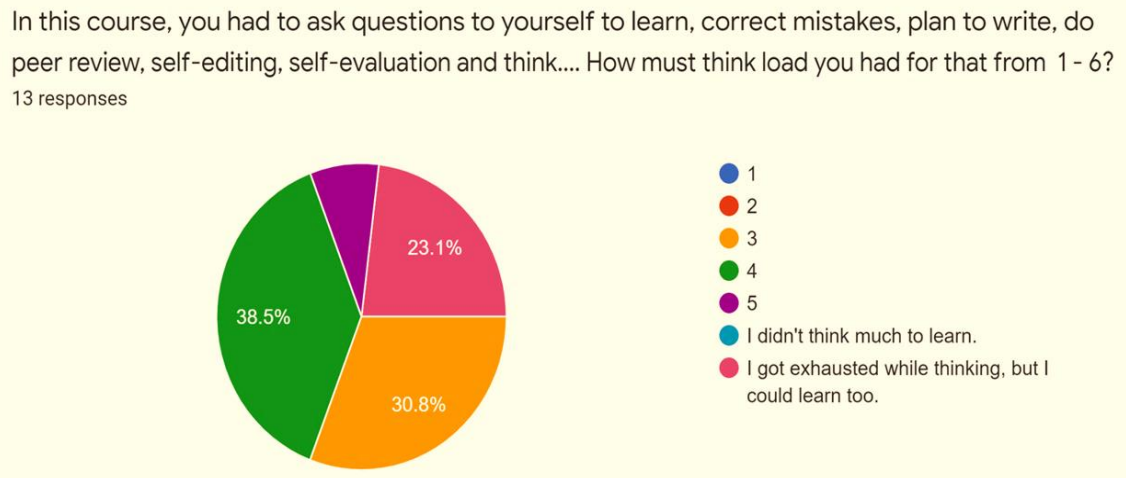

Figure 1Group A's self-report on cognitive involvement load

Figure 2 displays self-report of Group A's using metacognitive strategies at the end of the semester. The question was whether they learned about planning, organizing, monitoring, and evaluating own writing to improve. 84.6\% students reported as "YES", and 15.4\% students reported as "LEARNED SOME" of the metacognitive strategies. 

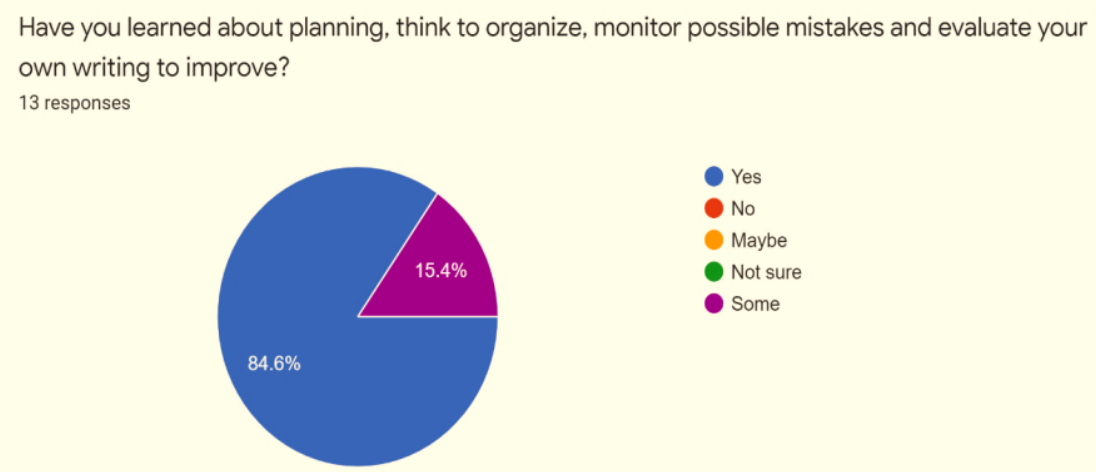

Figure 2Group A's self-report on metacognitive strategy use

Figure 3 demonstrates Group B student's self-report on using metacognitive strategies.42.9\% students confirmed trying to understand the task requirements before writing the draft 1, $14.3 \%$ students chose "STRONGLY YES", and 14.3\% studentschose "SOMEWHAT NOT". 18.6\% students were neutral about using the metacognitive strategies before starting a writing task.

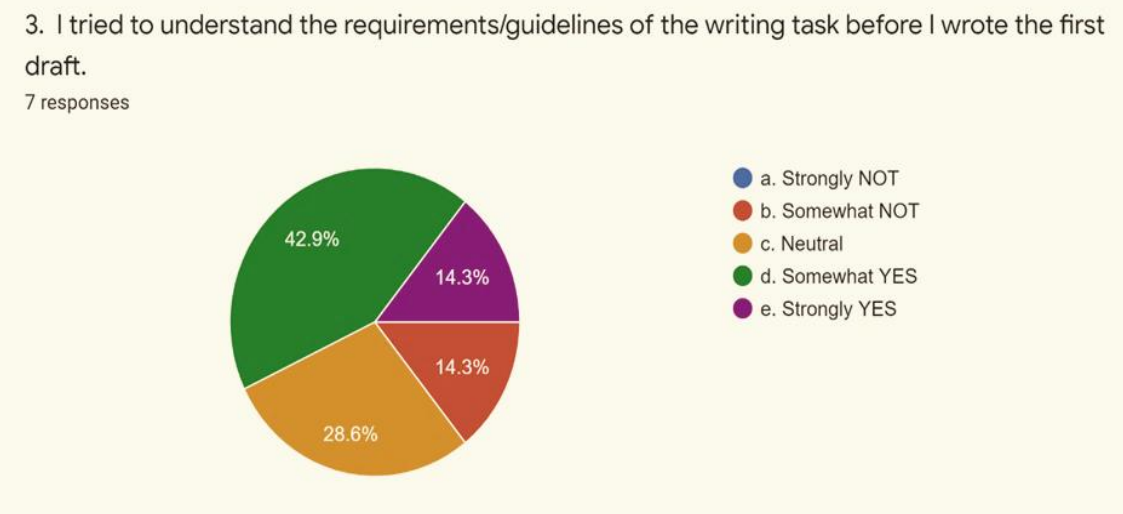

Figure 3Group B's self-report on application of a metacognitive strategy after pre test

Figure 4reveals Group B's self-report on application of the metacognitive strategiesduring the midsemester week. 57.1\% students confirmed "SOMEWHAT YES" about trying to understand the task requirements before starting a task and $42 \%$ students confirmed being "Neutral". But no student chose "NOT" for using strategies, which confirms students'being aware of usingmetacognitive strategies after receiving cognitive involvement load.

3.1 Now for the midterm, I tried to understand the requirements/guidelines of the writing task before I wrote the second draft.

7 responses

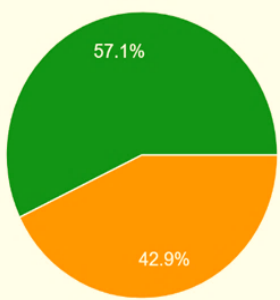




\section{Figure 4Group B's self-report on application of a metacognitive strategy after midterm test}

\section{Conclusion}

Theself-reportsin the pie charts above presentevidence of the participants developing self-regulated and metacognitive learning strategies. From the self-reports, it can be interpreted that the SILL2W could generate some understanding and willingnessamong learners for self-regulated learningandemploy metacognitive learning strategies. Based on the results, the answer to the first research question would be thattheS ${ }^{2} \mathrm{RMCA}$ model can be helpful for L2 writing learners to be self-regulated and improve L2 writing skills. The comparisons of test scores between the beginning and the end of the semester show statistically significant differences in the quality of writing skills and use ofthe learning strategies. While answeringthe second research question, it can be suggested that instructionally induced cognitive involvement load can facilitate use of self-regulated and metacognitive learning strategies for improving L2 writing.Students of both A and B groupshave reported experiencing high cognitive load and learning. The development and improvement in the writing qualities of the learners have confirmed that self-regulated and metacognitive learning strategy training if integrated in pedagogy can facilitate learner's self-regulated learning of L2 writing. Learners of this study have executed their learning management as planned in the $S^{2} \mathrm{RMCA}$ model through instructionally demanded and controlled selfregulated metacognitive actions. The instructional model $\mathrm{S}^{2} \mathrm{RMCA}$ and the instructional instrument SILL2W have been useful for teaching and learning self-regulated L2 writing in a regular classroom.

\section{Recommendations}

Based on the results and experience of this study,few suggestions can be offered. Teacher education programs should provide training on developing teaching approaches for enhancing self-regulation and metacognition.Pedagogy should provideguidance for learning management from early stages of learningwhich isnecessary for self-regulated learning at higher level of education.Pedagogical frameworks should be constructedfor educators and material developers to enhance self-regulation and metacognition in both formal and informal learning settings.Cognitive aspects of learning should not be overlooked by theoretical concernswhile developing pedagogical frameworks and teaching-learning materials. More studiesmay be carried out for strategic learning of all the skills of language learning.

\section{References}

1. Abidin, M. J. Z., \& Fong, C. L. (2012). The effect of process writing practice on the writing quality of form one students: A case study. Asian Social Science, $8(3), 88$.

2. Arndt, V. (1987). Six writers in search of texts: A protocol-based study of L1 and L2 writing. ELT journal, 41(4), 257-267.

3. Cao, Y. (2012). A study of metacognitive strategies in web-based English autonomous learning. IPEDR, 37, 66-69.

4. Chamot, A. U. (2018). Developing self-regulated learning in the language classroom. New perspectives on the development of communicative and related competence in foreign language education, 28, 4152.

5. Chamot, A. U., \& Harris, V. (Eds.). (2019). Learning strategy instruction in the language classroom: Issues and implementation. Multilingual Matters.

6. Chenoweth, N. A., \& Hayes, J. R. (2001). Fluency in writing: Generating text in L1 and L2. Written communication, 18(1), 80-98.

7. Conley, D. T. (2014). Learning Strategies as Metacognitive Factors: A Critical Review. Educational Policy Improvement Center.

8. Cotterall, S. (2000). Promoting learner autonomy through the curriculum: Principles for designing language courses. ELT journal, 54(2), 109-117.

9. Cubukcu, F. (2009). Learner autonomy, self-regulationand metacognition. International Electronic Journal of Elementary Education, 2(1), 53-64.

10. Cumming, A. (1989). Writing expertise and second-language proficiency. Language learning, 39(1), $81-135$.

11. De Larios, J. R., Murphy, L., \& Manchon, R. (1999). The use of restructuring strategies in EFL writing: A study of Spanish learners of English as a foreign language. Journal of Second Language Writing, 8(1), 13-44.

12. Dornyei, Z., \& Ryan, S. (2015). The psychology of the language learner revisited. Routledge. 
13. Evans, C. J., Kirby, J. R., \&Fabrigar, L. R. (2003). Approaches to learning, need for cognition, and strategic flexibility among university students. British Journal of Educational Psychology, 73(4), 507528.

14. Farrington, C. A., Roderick, M., Allensworth, E., Nagaoka, J., Keyes, T. S., Johnson, D. W., \& Beechum, N. O. (2012). Teaching Adolescents to Become Learners: The Role of Noncognitive Factors in Shaping School Performance--A Critical Literature Review. Consortium on Chicago School Research. 1313 East 60th Street, Chicago, IL 60637.

15. Gkonou, C., Tatzl, D., \& Mercer, S. (Eds.). (2016). New directions in language learning psychology. Springer International Publishing.

16. Griffiths, C. (2013). The strategy factor in successful language learning (Vol. 67). Multilingual Matters.

17. Gunning, P. (2011). ESL strategy use and instruction at the elementary school level: A mixed methods investigation (Doctoral dissertation, McGill University Library).

18. Hall, C. (1990). Managing the complexity of revising across languages. Tesol Quarterly, 24(1), 43-60.

19. Hayes, J. R., \& Flower, L. S. 1980. “Identifying the organization of writing processes.”. Cognitive processes in writing, 31-50.

20. Hayes, J. R. (2012). Modelling and remodelling writing. Written communication, 29(3), 369-388.

21. Hulstijn, J. H., \& Laufer, B. (2001). Some empirical evidence for the involvement load hypothesis in vocabulary acquisition. Language learning, 51(3), 539-558.

22. Macaro, E. (2006). Strategies for language learning and for language use: Revising the theoretical framework. The modern language journal, 90(3), 320-337.

23. Nopmanotham, N. (2016). A Study of Writing Strategies Used by Thai EFL High School Students. Thammasat University.

24. Olejnik, S., \&Nist, S. L. (1992). Identifying latent variables measured by the Learning and Study Strategies Inventory (LASSI). The Journal of experimental education, 60(2), 151-159.

25. O'malley, J. M., O'Malley, M. J., Chamot, A. U., \& O'Malley, J. M. (1990). Learning strategies in second language acquisition. Cambridge university press.

26. Oxford, R. L. (2017). 'The craft so long to lerne': aspects of time in language learning. Innovation in Language Learning and Teaching, 11(3), 282-297.

27. Oxford, R. (2018). Language learning strategies. The Cambridge Guide to Learning English as a Second Language, 81-90.

28. Oxford, R. L., \&Amerstorfer, C. M. (Eds.). (2018). Language learning strategies and individual learner characteristics: Situating strategy use in diverse contexts. Bloomsbury Publishing.

29. Phoocharoensil, S., Moore, B., Gampper, C., Geerson, E. B., Chaturongakul, P., Sutharoj, S., \& Carlon, W. T. (2016). Grammatical and Lexical Errors in Low-Proficiency Thai Graduate Students' Writing. LEARN Journal: Language Education and Acquisition Research Network, 9(1), 11-24.

30. Pour-Mohammadi, M., Zainol Abidin, M., \& Cheong Lai, F., (2012) The effect of process writing practice on the writing quality of form one students: A Case Study. Asian Social Science, 8(3), 88-99.

31. Pressley, M., Mohan, L., Fingeret, L., Reffitt, K., \& Raphael-Bogaert, L. (2007). Writing

32. Raya, M. J. (2011). Enhancing pedagogy for autonomy: the potential of a case-based approach in promoting reflection and action. Innovation in Language Learning and Teaching, 5(2), 151-163. Retrieved 7 7, 2020, from https://tandfonline.com/doi/full/10.1080/17501229.2011.577531

33. Rose, H. L. (2012). Language learning strategy research: Where do we go from here? In Studies in Self-Access Learning Journal, 3(2).

34. Sasaki, M. (2000). Toward an empirical model of EFL writing processes: An exploratory study. Journal of second language writing, 9(3), 259-291.

35. Sweller, J. (1988). Cognitive load during problem solving: Effects on learning. Cognitive science, 12(2), 257-285.

36. Tseng, W. T., Dörnyei, Z., \& Schmitt, N. (2006). A new approach to assessing strategic learning: The case of self-regulation in vocabulary acquisition. Applied linguistics, 27(1), 78-102.

37. Weinstein, C. E., \& Palmer, D. R. (2002). LASSI. User's Manual for those administering Learning and Study Strategies Inventory (2nd Edition). Clearwater, FL: H\&H Publishing Company.

38. Whalen, K., \& Menard, N. (1995). L1 and L2 writers' strategic and linguistic knowledge: A model of multiple-level discourse processing. Language learning, 45(3), 381-418.

39. Zimmerman, B. J., \& Schunk, D. H. (2008). An essential dimension of self-regulated learning. Motivation and self-regulated learning: Theory, research, and applications, 1. 